\title{
The 21st Century Terrorist: Hostis Humani Generis?
}

\author{
Elimma C. Ezeani \\ Robert Gordon University, Aberdeen, UK. \\ Email: e.ezeani@rgu.ac.uk \\ Received September $7^{\text {th }}, 2012$; revised October $8^{\text {th }}$, 2012; accepted October $21^{\text {st }}, 2012$
}

\begin{abstract}
Some argue that 21st century terrorism is no different from the past. This paper argues otherwise. It considers that our social response-The revulsion against the frequent violation of the sanctity of human life and the indiscriminate destruction of property death-Ought to be the most important factor in any attempt to categorise terrorists under international criminal law. Such a proper categorisation is as common enemies of mankind. Section 1 revisits the challenge of definition and of jurisdiction; Section 2 examines the current approaches to terrorism-Domestic, bilateral and international; and Section 3 concludes the argument whether the 21st century terrorist is a common enemy of mankind. The need for alternative social responses if the roots of modern terrorism are to be addressed is also examined.
\end{abstract}

Keywords: 21st Century Terrorist; Common Enemies of Mankind; Definition; Jurisdiction and Punishment; Human Rights and Extradition; Terror

\section{The Retained Challenges of Definition and Jurisdiction}

"The idea of systematically defining terrorism as an international criminal offence only gathered momentum in the 1920s and 1930s [1]". ${ }^{1}$ The International Law Commission (ILC) 1954 Draft Code of Offences against Peace and Security of Mankind (Part I) had identified terrorism as aggression and as a crime under international law, with individual criminal responsibility. ${ }^{2}$ Regardless, the several attempts to reach agreement on an international "generic definition" whether at the League of Nations, United Nations, or by the ILC did not come to fruition, although an "ad-hoc" committee created under a UN General Assembly resolution to consider these matters in 1972 remained. ${ }^{3}$ In 1996, a final draft Code to the ILC's 1954 attempt (Part II) included the offence of terrorism, but as a "war crime", 4 thereby linking terrorism with armed conflict. However, the Code was not adopted.

The reasons for this difficulty are not far-fetched. For states, there was a difficulty (which still persists) with reaching an acceptance on what terrorism was, partly for reasons of disagreement over whether to criminalise what some considered an ideological l or political movement [2]. ${ }^{5}$ This difficulty was an extension of the political con-

${ }^{1}$ B. Saul, Attempts to Define "Terrorism” in International Law, Netherlands International Law Report (NILR) (2005) 57-83 at 58. See also, B. Saul, Defining Terrorism in International Law (New York: Oxford University Press, 2006)

${ }^{2}$ See B. Saul, op cit NILR, 66.

${ }^{3}$ UN G.A. 27/3034, op cit.

${ }^{4}$ Ibid, 72. undrum seen in States where political opponents were labelled "terrorists" with the same "terrorists" seen as freedom fighters more concerned for the welfare of the people than the ruling government [3]. ${ }^{6}$ Groups like the African National Congress (ANC), the Palestine Liberation Organisation (PLO), and Hamas who at various times adopted terror attacks in furtherance of their objectives would eventually gain legitimacy not least because they aroused the interests, sympathy, or fear, of the people around them [4]. ${ }^{7}$

The hesitation by States may also be due to the fact that States themselves have been accused of terrorist activity either on the grounds of state terrorism by tyrannical regimes ${ }^{8}$ or of state-Sponsored terrorism. ${ }^{9}$ Allegations of terror are also made against apparently "non-

\footnotetext{
${ }^{5}$ See A. Cassesse, The Multifaceted Criminal Notion of Terrorism in International Law, Journal of International Criminal Justice (2006) 126, 2.

${ }^{6}$ See B. Saul, "Definition of 'Terrorism' in the UN Security Council: 1985-2004,” 4 Chinese Journal of International Law (CJIL) (2005) doi:10.1093/chinesejil/jmi005 accessed July 2, 2012.

${ }^{7}$ See generally, A. Van Engeland and R. M. Rudolph, From Terrorism to Politics (Hampshire: Ashgate, 2008).

${ }^{8} \mathrm{P}$. Wilkinson, “Can a State Be 'Terrorist'?” 57 International Affairs 3 (1981) 467-472, at 468; cf K. Duncan, "A Blast from the Past: Lessons from a Largely Forgotten Incident of State-Sponsored Terrorism," 5 Perspectives on Terrorism (2011), 3-21; C. C. Combs, Terrorism in the Twenty-First Century (Prentice Hall $7^{\text {th }}$ Edition, 2012), Chapter I.

${ }^{9}$ For a distinction between the two concepts, see M. Cherif Bassioni, "Legal Control of International Terrorism: A Policy-Oriented Assessment,” 43 Havard International Law Journal 1 (2002), 83-103 at 84-85 5. Cf A. George, Ed., Western State Terrorism (Polity Press, 1991); R. Jackson, E. Murphy, S. Poynting, Eds., Contemporary State Terrorism Theory and Practice (London: Routledge, 2009).
} 
tyrannical” regimes such as the concerns with Western military activity in Iraq, Afghanistan, and specifically, US unilateral action in Pakistan post 9/11. Self-defence under Article 51 of the UN Charter has provided the excuse for such unilateral attacks [5]. ${ }^{10}$ Tam observes that this has empowered States "to exercise force against attacks by non-state actors-attacks which would have been difficult to justify under the traditional approach". ${ }^{11}$

The morning after 9/11, the UN in Resolution 1368 called on all States in the international community "to work together urgently to bring to justice the perpetrators, organizers and sponsors of these terrorist attacks" stressing that "those responsible for aiding, supporting or harbouring the perpetrators, organizers and sponsors of these acts will be held accountable". ${ }^{12}$ The Resolution recognised "the inherent right of individual or collective selfdefence in accordance with the Charter". ${ }^{13}$ This recognition of the right to self-defence in the face of terrorist threats "implied that the attacks triggered the right even if, at the time of the adoption, the UN Security Council knew almost nothing about who or what had launched them [6]." 14

This has provided grounds for the US targeted killings in Pakistan in its hunt for terrorists, post $9 / 11 .{ }^{15}$ It has had its successes: the US finally killed Osama bin Laden the leader of Al-Qaeda and instigator of 9/11 on 2 May 2011, in Pakistan. However, such targeted killing even for the specific purpose of responding to terrorism threats is not very far from the very violence of the terrorism it presumes to counter. ${ }^{16}$ It also exacerbates tension between states: the US operation in killing bin Laden was condemned by Pakistan as a violation of the latter's sovereignty [7]. ${ }^{17}$

In any event, 9/11 did serve to alert the world to the dangers of globalised terror given that as Bassioni had

\footnotetext{
${ }^{10}$ See generally, C. J. Tams, "The Use of Force against Terrorists” European Journal of International Law 20 (2009), 359-397.

${ }^{11}$ Ibid, 369.

${ }^{12}$ Italics for emphasis. See UN SC ResN 1368, U.N.SCOR $56^{\text {th }}$ Session, 12 Sept 2001.

${ }^{13}$ Ibid.

${ }^{14} \mathrm{~N}$. Rostow, "Before and After: The Changed UN Response to Terrorism since Sept 11” 35 Cornell International Law Journal 35 (2001) 475 at 481.

${ }^{15}$ This significant counterterrorism measure by the US involves moral, legal and political arguments on either side of the debate. See M. O'Connell, "The Choice of Law against Terrorism" Journal of National Security Law and Policy 4 (2010), 343-368. Cf K. Anderson: “Targeted Killings in US Counter-Terrorism Strategy and Law” (May 11, 2009). Available online: http://ssrn.com/abstract=1415070 accessed 29 June 2012; G. Blum and P. Heymann, "Law and Policy of Targeted Killing” Harvard National Security Journal 1 (2010) 145-170.

${ }^{16}$ See further, J. J. Paust, "Self-Defense Targetings of Non-State Actors and Permissibility of US Use of Drones in Pakistan," Journal of Transnational Law \& Policy, 19 (2010), 237; A. J. Radsan and R. W. Murphy "Due Process and Targeted Killing of Terrorists," Cardozo Law Review, 31 (2009) 405. See also, G. Blum and P. Heymann, Laws, Outlaws and Terrorists: Lessons from the War on Terrorism (Massachu setts: MIT Press 2010).
}

noted earlier, "the manifestations of terrorism and the means to prevent and control them have long been studied but governments have tended to ignore the dangers.”18 Legal commentators have always pointed to the political aim of terrorism and Hoffman's definition-that terrorism is "thus violence-or equally important, the threat of violence-used and directed in pursuit of, or in service of, a political aim [8]"19 captures this well. Cassesse expanded the commentary, suggesting that international terrorism could be construed in three ways: either as a war crime, or a crime against humanity, or in the alternative, a discrete crime (when the acts do not fall under the category of war crimes or crimes against humanity) [9]. ${ }^{20}$ The United Nations (UN) has also continued attempts at a composite definition. Based on a first draft submitted by India as member of the UN Working Group on Measures to Eliminate International Terrorism, ${ }^{21}$ in the current Draft Comprehensive Convention on International Terrorism, ${ }^{22}$ the Organisation has set out the ingredients of the offence of terrorism. Article 2(1) provides that a person with the purpose of intimidating a population or compelling a Government or international organisation to do or abstain from an act, commits an offence under the Convention by unlawfully or intentionally causing death or serious bodily injury (Art 2(1) a), damage to public or private property resulting or likely to result in major economic loss (Art 2(1) b - c).

The Draft Convention remains contentious for a variety of reasons [10]. ${ }^{23}$ These include the exact definition of the crime of terrorism, the scope of the convention and its overlap with other conventions regulating the use of force and other terrorist-related conventions, and whether the crime is applicable to situations of armed conflict and its potential impact on a State's regular armed forces. It could have defined or excluded groups which ought not to be caught by the Convention. It appears the UN is pre-

\footnotetext{
${ }^{17}$ See T. Wright, "Pakistan Criticises US raid on bin Laden" Wall Street Journal (May 3 2011). http://online.wsj.com/article/SB100014240 52748703922804576301124180651068.html

${ }^{18} \mathrm{M}$. Cherif Bassiouni, op cit at 83.

${ }^{19} \mathrm{~B}$. Hoffman, Inside Terrorism (New York: Columbia University Press 1998), 15.

${ }^{20} A$. Cassesse, International Law $\left(2^{\text {nd }}\right.$ Edition, New York: Oxford University Press 2005), 450, referring to Para 3, Declaration on Measures to Eliminate International Terrorism, UNGA resolution 49/60, adopted on 9 December 1994; See also, the supplementary Declaration on Measures to Eliminate International Terrorism GA 51/210.

${ }^{21}$ See "Report of the Working Group", Measures to Eliminate International Terrorism UN Doc A/C.6/55/L.2 of 19 October 2002 in its Annex II.

${ }^{22}$ See also the UN Draft Comprehensive Convention on International Terrorism (Report of the Ad Hoc Committee Established by the General Assembly Resolution 51/210 17 Dec 1996, UN GAOR, $6^{\text {th }}$ Sess, UN Doc A/57/37 (2002). The Ad-Hoc Committee was supported with the General Assembly's Sixth Committee (the Working Group)).

${ }^{23}$ See further M. Hmoud, "Negotiating the Draft Comprehensive Convention on International Terrorism-Major Bones of Contention," Journal of International Criminal Justice 4 (2006) 1031-1043.
} 
pared to err on the side of caution and rightly so, on this aspect of a definition given the contention over the application of the term "terrorist" to for example, national military forces and self-liberation movements. ${ }^{24}$ However adopting the term "any person" surely leaves the jurisdiction of the draft convention wide enough to cover all manners of persons.

By eschewing any defences on political, philosophical, ideological, racial, ethnic, religious or any other similar considerations, the draft Convention attempts to prevent the stumbling blocks earlier attempts on reaching a consensus on the issue have faced. ${ }^{25}$ While it incorporates the aut dedere aut judicare provision, it precludes the reliance on political exceptions for the "purposes of extradition or mutual legal assistance"; thus "none of the offences referred to in article 2 shall be regarded as a political offence or as an offence connected with a political offence or as an offence inspired by political motives." 26

A shortcoming of the Convention in our view is that it does not incorporate in its definition of terrorism, the publicity-seeking, unbridled violence, global impact, and indiscriminate nature of terrorist attacks. The language of the Convention does not reveal a revulsion against these common factors of modern terrorism. Also, by restricting the definition to "international terrorism" it fails to acknowledge that much of the terrorism we later come to know about originate from, and perpetuate in, the domestic arena. Further still, while a political motive may have been behind historical terrorist activity, it is not necessarily the case that political domination is the primary motive of present terrorist activity. Furthermore, contrary to the idea that there is always a defined agenda for terrorism, an enduring view promoted by the avowed political leanings of terrorist groups, there may not be a single definite agenda behind terrorist action; or indeed the real agenda may be different from public understanding.

What if terrorist action is not taken with the intention of compelling a government or international organization? It is probable that terrorist activity may be to further its own peculiar agenda including one that desires economic power and that the intimidation of governments or organization is merely a means to an end and not the end itself. Terrorist action may be chosen not so much because there is a deadline or timeframe for an expected outcome upon which the terrorist activity will cease but just because it will draw attention to the perpetrators, create fear in the public, and panic governments into fearing for their security. We may be limited in our understan-

\footnotetext{
${ }^{24}$ See the proposal by Malaysia on behalf of the OIC-See Report of the Working Group, op cit Annex III.

${ }^{25}$ Article 5 of the Draft Convention.

${ }^{26}$ Ibid, art 14.
}

ding of what truly motivates terrorists given the variety of possible factors that drive terrorism today but it is folly to presume that there is a definable "other" end to terrorism: the sole objective of terrorism is simply terror.

Nevertheless, while definitions are integral to an appropriate regime for terrorism, it is imperative that the revulsion against the suffering of victims-revulsion against the crime itself and not necessarily the motive behind it-should be prioritised. Recalling Cassese's arguments in view of a concise definition of terrorism, the "general revulsion against this crime warrants the conclusion that any State is legally entitled to bring to trial the alleged authors of such acts of terrorism who happen to be on its territory" ${ }^{27}$ But what is the "general revulsion" against - the motive or the action? Surely the revulsion is really to the action - the violation of our common humanity and disregard for the sanctity of human lifenot necessarily the motive which may not even be known. Rehman warns that terrorism is an elusive concept and one that is perhaps not worthwhile to pursue $[11],{ }^{28}$ however, "terrorist activity" is a constant feature of news around the world and the threats continue to spread. Terrorists themselves are not as elusive as in the past; in fact now, they wish to be identified, hence the increased use of social media to present their views ${ }^{29}$ and the dependence on the mass media to publicise not just their activity but their claims of responsibility.

States and other groups with their different positions on issues of politics, religion and economic power, and who should determine these questions, are not agreed on what constitutes an appropriate definition of terrorism in so far as a motive or ideology is concerned. But there can be no disagreement of the terrible effects of terrorist activity felt all around the world. Indeed it could be argued that a concrete definition of terrorism under international law may be found in the recent ruling of the Special Tribunal for Lebanon Appeals Chamber in its 2011 interlocutory decision where it was stated that there are three elements in the emerging customary rule of international law on terrorism:

1) The perpetration of a criminal act (such as murder, kidnapping, hostage-taking, arson, and so on), or threatening such an act; 2) the intent to spread fear among the population (which would generally entail

\footnotetext{
${ }^{27}$ A. Cassesse, International Law op cit, 450.

${ }^{28}$ J. Rehman, International Human Rights Law $\left(2^{\text {nd }}\right.$ Edition England: Pearson Education Ltd., 2010), 879.

${ }^{29}$ See J. Qin et al., "Analysing terror campaigns on the internet: Technical sophistication, content richness and Web interactivity,” International Journal of Human-Computer Studies 65(2007), 71-84. However the adoption of the media as a tool for terrorist propaganda extends to more than web sites to include the press, radio, and television media as well. Cf M. Dubowitz, "Wanted: A War on Terrorist Media," The Journal of International Security Affairs, 17 (2009) Online at http:// www.securityaffairs.org/issues/2009/17/dubowitz.php accessed July 2 2012.
} 
the creation of public danger) or directly or indirectly coerce a national or international authority to take some action, or to refrain from taking it; $3 \mathrm{i}$ ) when the act involves a transnational element [12]. ${ }^{30}$

It is still too early to determine the impact of this ruling and to what extent it will change the consensus on terrorism in the international community. One hopes that the carefully considered 150 page judgment of the Appeals Chamber particularly in its review of terrorism under international law will have a defining impact for the future. It will of course attract resistance and criticism. Nevertheless, controversies over defining terrorism will not extinguish the need for practical efforts to address this crime. It is therefore important to evaluate the current approaches to jurisdiction and punishment of terrorism today.

\section{Current Approaches to Terrorism}

This can be viewed from three perspectives: domestic; bilateral; and international:

\subsection{Domestic Approach}

Some countries have enacted anti-terrorism or related security legislation. These include legislation earlier designed as a response to the violent activity of dissident political groups or more specifically for anti-terrorism purposes. More recent and composite national definitions on terrorism has since emerged in responses to terrorist threats; such legislation were extensively reviewed by the Special Tribunal for Lebanon Appeals Chamber in its 2011 interlocutory decision. ${ }^{31}$ Response to terrorism at domestic level is more reactive than proactive; it is more likely that a State which has experienced or expects to experience some form of terrorist activity will respond with legislation. Some may not. Yet, the greater majority of terrorist threat is actually domestic, and not transnational [13]. ${ }^{32}$ Young and Findley consider this to be an issue in reaching a composite definition of terrorism since the findings in this regard "suggests that much of what we know might apply only to a small portion of overall terrorism."

It is not only the definition that is problematic; terrorism is diverse in its causes, motives, targets, weaponry, sophistication, leadership, organization, mission, agenda, location, and pursuit of economic power. For States faced with the challenges of organizing and maintaining

\footnotetext{
${ }^{30}$ See STL Appeals Chamber: "Interlocutory Decision on the Applicable Law: Terrorism, Conspiracy, Homicide, Perpetration, Cumulative Charging,” STL-11-01/1, 16 Feb 2011, para 85.

${ }^{31}$ Ibid, pp. 57-63.

${ }^{32}$ See generally, J. K. Young and M. G. Findley, "Promise and Pitfalls of Terrorism Research” International Studies Review, 13 (Sep 2011), pp. 411-439

${ }^{33}$ Ibid, 417.
}

a social system and government, the insecurity of terrorist activity is only one of a multitude of concerns. Organizing a cogent response to terrorist threats requires a strong effective approach to law enforcement, financial and human resources, and a robust judicial framework that can oversee efforts at apprehending terror suspects. This of course requires that States understand the spillover effects of terrorist activity: even though the threat may be within the geographical space of one State, funding, arming, training, and increasingly the targets of perpetrators, are hardly ever limited to that geographical location alone. This is why bilateral action offers greater chances of success with States pulling resources together towards this end but as we see next, even established bilateral mechanisms are not without their own tests.

\subsection{Bilateral Action}

At bilateral level, the ability of States to apprehend or try alleged terrorists is a test of the State's security, political, and judicial capacity. Well trained security forces, understanding between governments, and a strong judicial system which enshrines the rule of law must be in place. These requirements have been put to the test in as between the UK and US, in their counter-terrorism efforts post 9/11, and bilateral action here is instructive:

\section{Challenges: Extradition and Human \\ Rights-The UK-US Post 9/11}

Extradition and the rights of the individual, has always been an issue in international law [14]. ${ }^{34}$ Extraditing terror suspects is no less problematic not least because terror suspects regardless of the severity of the alleged crime should still be able to avail themselves of the rights and liberties they are due under the rule of law.

In the UK, the Human Rights Act (HRA) ${ }^{35}$ would become a point of contention in extradition requests by the US, to the UK primarily, the provisions on prohibition of torture, ${ }^{36}$ and the right to a fair trial. ${ }^{37}$ The HRA proved invaluable for the defence in recent high profile extradition cases including the Natwest $3,{ }^{38} \mathrm{Abu}$ Hamza \&

\footnotetext{
${ }^{34}$ See J. Dugard and C. van den Wyngaert, "Reconciling Extradition with Human Rights” American Journal of International Law 92 (1998), 187-212 at 187.

${ }^{35}$ Incorporating Articles 2 to 12 and 14 of the ECHR, Articles 1 to 3 of the First Protocol, and Articles 1 and 2 of the Sixth Protocol, read in conjunction with Articles 16 to 18 of the Convention. See S.1, HRA 1998.

${ }^{36}$ Article 3 HRA 1998; also Article 3 of the UN Convention against Torture and other Cruel, Inhuman or Degrading Treatment or Punishment-UN G. A. Res 39/46 10 Dec 1984. Other relevant international legislation prohibiting inhuman or degrading treatment include Art 5 Universal Declaration of Human Rights (UDHR); Art 7 International Covenant on Civil and Political Rights (ICCPR); common Art 3 of the 4 Geneva Conventions and Arts 50 (I), 51 (II), 130 (III), and 147 (IV).

${ }^{37}$ Ibid, Article 6; Art 3 ECHR.

${ }^{38}$ Bermingham v Director of the Serious Fraud Office (2007) 2 W. L. R. 635.
} 
ors, ${ }^{39}$ and the Gary Mckinnon case. ${ }^{40}$ The antecedents for this reliance can be traced to the Soering case. ${ }^{41}$ There, the European Court of Human Rights (ECrtHR) noted that the European Convention on Human Rights (ECHR) "is a search for the fair balance between the demands of the general interest of the community and the requirements of the protection of the individual's fundamental rights". ${ }^{42}$ Prior to this case, there was "no explicit general rule saying that extradition should be compatible with human rights [15]". ${ }^{43}$ Wyngaert points out that the argument has often been that the requested person's rights will take place only "after" his extradition, and that it is within the jurisdiction of the requesting State and not the requested State that any potential human rights violations are to occur. ${ }^{44}$ The practice has been that the anticipation of potential violations in a requesting State cannot be a valid argument against extradition: the principle of noninquiry [16]. ${ }^{45}$

The UK Extradition Act 2003 under Section 21 regarding extradition to Category 1 territories, (pursuant to Sections 11 and 12$)^{46}$ set out considerations to be undertaken prior to extradition. If the judge decides extradition is compatible with Convention rights, the person is to be remanded in custody or in bail to await extradition to the category 1 territory where the warrant was issued. If the judge decides in the negative, the person is to be discharged. For Category II territories i.e. countries not operating the European Arrest Warrant System, such as the US, S 87 provides that where the judge decides the extradition is incompatible with the Convention rights, he must order the person's discharge. Where the judge decides in the affirmative, the case is sent to the Secretary of State for a final decision.

Compliance with the HRA is therefore a preliminary requirement making it more difficult for an expeditious extradition process as was probably expected when the 2003 arrangements were made. The UK Extradition Treaty (2003) between the UK and the US, ${ }^{47}$ "the Treaty" provides that conduct punishable with the deprivation of liberty for more than one year or by a more severe penalty under both states is an extraditable offence. ${ }^{48}$

The case of Abu Hamzar and three others wanted in

\footnotetext{
${ }^{39}$ See Mustafa Kamel Mustafa $v$ Government of the United States of America and Secretary of State for the Home Department (2008) EWHC 1357.

${ }^{40}$ McKinnon v Government of the United States of America and Another [2008] UKHL 59.

${ }^{41}$ E.C.H.R. Ser A, No 161, 7 July 1989.

${ }^{42}$ Ibid, para 89.

${ }^{43}$ See C. van Den Wyngaert, "Applying the European Convention on Human Rights to Extradition: Opening Pandora’s Box?” International Comparative Law Quarterly 39 (1990) 757-779 at 758.

${ }^{44}$ Ibid, 760.

${ }^{45}$ See M. Cherif Bassiouni, International Extradition, United States Law and Practice (1983) Vol. VII, para. 7-1, cited in Wyngaert, id, 760.

${ }^{46}$ "Bars to extradition" and "Rule against double jeopardy".
}

the United States on counts of terrorism reflects the challenges to extraditing terror suspects. Extradition of the four men in the case had already been approved by a UK court and the Secretary of State and leave to appeal to the House of Lords had been declined. At the High Court on appeal by Hamza, three human rights arguments against extradition were raised: extradition was contrary to Article 3 ECHR because the extradition was founded on evidence obtained by torture or ill treatment and there was a "real risk" that the appellant would be subjected to torture or ill treatment upon extradition; there would be a "disproportionate interference with his rights under Article 8; and given the passage of time since the alleged offences were committed, it was "unjust and oppressive" to order extradition. ${ }^{49}$

Concerning Art 3, the appellant pleaded his medical conditions $^{50}$ arguing that lengthy incarceration in the "Supermax" prisons would amount to ill treatment. In the opinion of the court, the lengthy incarceration and "likelihood" of life sentence "of itself would not constitute a breach of Article 3". ${ }^{51}$ Noting further than there is "a considerable body of unchallenged evidence about the conditions in Supermax prisons generally" the Court declined this argument as well. ${ }^{52}$ The suggestion that trial in the USA would be contrary to Article 6 of the ECHR, was rejected on the basis of US "history of unswerving compliance" with their diplomatic assurances. ${ }^{53}$ The argument that Article 8 of the ECHR would be contravened by the long incarceration abroad, curtailing the contact between the appellant and his family, was not accepted. The court was of the view that "Long periods of incarceration were not only "inevitable" but also "amply justified" in the circumstances. ${ }^{54}$

On 8 July 2010 however, the ECrtHR acknowledged in part, that certain human rights questions needed to be answered by the UK government before Hamza and the others could be extradited to the US. ${ }^{55}$ The Court declared the following issues to be "partially admissible":

\footnotetext{
${ }^{47}$ This treaty is preceded by the United Kingdom of Great Britain and Northern Ireland Extradition Treaty 1972 (1972 Treaty), and the Supplemental Treaty Concerning the Extradition Treaty Between the Government of the United States of America and the Government of the United Kingdom of Great Britain and Northern Ireland (June 1985) (Supplementary Treaty). The latter was mainly agreed in order to set out offences which would not be excluded in an extradition request as being political in nature. See Art.1 Supplementary Treaty.

${ }^{48}$ See further Article 2 (4) of the Treaty.

${ }^{49}$ See the HC decision: Mustafa Kamel Mustafa $v$ Government of the United States of America and Secretary of State for the Home Department (2008) EWHC 1357, 20 June 2008, op cit, para 8.

${ }^{50}$ Type 2 diabetes, poor eye sight, and amputated limbs.

${ }^{51}$ (2008) EWHC 1357, 20 June 2008, para 64.

${ }^{52}$ Ibid, para. 65.

${ }^{53}$ Ibid, para. 62.

${ }^{54}$ Ibid para. 72.

${ }^{55}$ Decision on Admissibility Baba Ahmad and Others $v$ the United Kingdom Application nos 24027/07, 11949/08 and 36742/08, 8 July 2010.
} 
complaints by all except Abu Hamza under Article 3 (prohibition of inhuman or degrading treatment) about possible post-trial detention in a United States of America prison with the highest possible of security levels (a "supermax" prison); and the length of the sentences in the USA for all four applicants in relation to Article $3{ }^{56}$ The UK Government was therefore asked to provide answers to the following questions vis a vis: whether the period of incarceration in a supermax prison would amount to a violation of Article 3 and whether the applicants have any "real prospect" of being transferred to a normal prison; whether the Eighth amendment to the US Constitution on cruel and unusual punishment as interpreted by US federal courts cover the protection offered under Article 3. In addition, it was also asked to ascertain whether there exists the possibility of a reduction in the sentences after conviction. In April 2012, the European Court finally ruled in favour of the extradition of the four men to the US conceding that "supermax" prisons were not in violation of the accused's human rights. ${ }^{57}$ Notwithstanding this ruling, in September 2012, Abu Hamza and others again appealed this last decision of the ECrtHR in the UK High Court but the appeal was turned down. The four men were finally extradited to the US on 5 October 2012. The entire process took eight years.

The bilateral approach despite its challenges is evidently successful at least on the basis of the examination above. It does however require that both states agree on the double criminality requirement i.e. that the offence is criminal in the two jurisdictions; that there is extradition agreement between the two; and that the courts are satisfied on the procedure for law enforcement [17]. ${ }^{58}$ However, the difficulties examined as between two highly developed systems, the US and the UK pale into insignificance when States with weak legal, social and political structures, are assessed for their capacity for bilateral or regional containment of terrorism. Plagued by internal conflicts, proliferation of and black market trade in, arms and ammunitions, insecure borders, poverty, a corrupt public service system, civil unrest and poor human rights protection, countries with these records which include

${ }^{57}$ See BBC News: “Abu Hamza US Extradition Backed by European Court,” http://www.bbc.co.uk/news/uk-17657814; accessed 28 June 2012. See "Abu Hamza makes high court bid to avoid extradition," The Guardian (UK) 2 October 2012, at http://www.guardian.co.uk/ uk/2012/ oct/02/abu-hamza-high-court-extradition; accessed 2 October 2012.

${ }^{58}$ For an American analysis see also, D. S. Kris, "Law Enforcement as a Counterterrorism tool”, Journal of National Security Law and Policy 5 (2011) 1-95.

${ }^{59}$ See J. Cilliers, “Terrorism and Africa” 12 African Security Review 4 (2003) 91-103.

${ }^{60}$ Cf B. Vaughan et al., "Terrorism in South East Asia” CSR Report for (US) Congress, Oct 2009; P. Chalk, et al. The Evolving Terrorist Threat to South East Asia A Net Assessment (Virginia: RAND Corp 2009).
}

many countries in Africa [18 ${ }^{59}$, and in Asia $[19]^{60}$, are not only fertile ground for terrorists but individually, may not be able to offer an effective legal system for addressing the threats of terrorist activity.

\subsection{International Approach}

Terrorism in contemporary times "has recently acquired a new intensity [20]" ${ }^{61}$ Measures to address this have seen a marked improvement on the situation in 1972 when the UN first attempted to reach an agreement on the issue.$^{62}$ Currently, there are about twenty international agreements on terrorism: five at the United Nations, ${ }^{63}$ eight multilateral agreements, ${ }^{64}$ and seven at regional level. ${ }^{65}$ Most of these agreements adopt the view that jurisdiction over terrorist activities is in some form universal; Shaw notes that the agreements "operate on a common

\footnotetext{
${ }^{61} \mathrm{M}$. Shaw, International Law ( $6^{\text {th }}$ Edition Cambridge: Cambridge University Press 2008), 1159.

${ }^{62}$ See "Measures to Prevent International Terrorism” G. A. Res 27/3034 cited in M. Halberstam, "The Evolution of the United Nations Position on Terrorism: From Exempting National Liberation Movements to Criminalising Terrorism Wherever and by Whomever Committed" Columbia Journal of Transnational Law, 41 (2002-2003), 572-584 at 573.

${ }^{63}$ Convention on the Prevention and Punishment of Crimes against Internationally Protected Persons, including Diplomatic Agents 14 Dec 1973 (in force 20 Feb 1977); International Convention against the Taking of Hostages 17 Dec 1979 (in force 3 June 1983); International Convention for the Suppression of Terrorist Bombings 15 Dec 1997 (in force 23 May 2001); International Convention for the Suppression of the Financing of Terrorism 9 Dec 1999 (in force 9 Dec 1999); International Convention for the Suppression of Acts of Nuclear Terrorism 13 April 2005 (in force 7 July 2001).

${ }^{64}$ Convention on Offences and Certain Other Acts Committed on Board Aircraft, Tokyo 14 Sep 1963-International Civil Aviation Organisation (ICAO); Convention for the Suppression of Unlawful Seizure of Aircraft, Hague 16 Dec 1970—Russian Federation UK, USA; Convention for the Suppression of Unlawful Acts against the Safety of Civil Aviation Montreal 23 Sep 1971—Russian Federation, UK, USA; Convention on the Physical Protection of Nuclear Material Vienna 3 March 1980-International Atomic Energy Agency (IAEA); Protocol on the Suppression of Unlawful Acts of Violence at Airports Serving International Civil Aviation, Supplementary to the Convention for the Suppression of Unlawful Acts against the Safety of Civil Aviation, Montreal 24 Feb 1988-Russian Federation, UK, USA, ICAO; Convention for the Suppression of Unlawful Acts against the Safety of Maritime Navigation 10 March 1988-International Maritime Organisation (IMO); Protocol for the Suppression of Unlawful Acts against the Safety of Fixed Platforms Located on the Continental Shelf 10 March 1988IMO; Convention on the Marking of Plastic Explosives for the Purpose of Detection 1 March 1991-ICAO.

${ }^{65}$ Arab Convention on the Suppression of Terrorism, League of Arab States 22 April 1998; Convention of the Organisation of the Islamic Conference on Combating International Terrorism OIC, 1 July 1999; European Convention on the Suppression of Terrorism, Council of Europe, 27 Jan 1977, OAS Convention to Prevent and Punish Acts of Terrorism Taking the Form of Crimes against Persons and Related Extortion that are of International Significance Organisation of American States 2 Feb 1971; OAU Convention on the Prevention and Combating of Terrorism African Union 14 July 1999; SAARC Regional Convention on Suppression of Terrorism, South Asian Association for Regional Cooperation 4 Nov 1987; Treaty on Cooperation among States Members of the Commonwealth of Independent States in Combating Terrorism CIS, 4 June 1999.

${ }^{66}$ Op cit, 1160.
} 
model, establishing the basis of quasi-universal jurisdiction with an interlocking network of international obligations ${ }^{\prime 66}$. Halberstam notes that the UN's position on terrorism has changed from one that at least arguably permitted terro- rism in support of the struggle for self-determination, to one that unequivocally condemns terrorism as criminal and unjustifiable wherever and by whoever committed. ${ }^{67}$

More recently in 2011, the aforementioned Appeals Chamber of the Special Tribunal for Lebanon in a pretrial ruling extensively investigated the definition of terrorism in international law. The Tribunal's guidelines clearly set out that the crime of terrorism was to be interpreted in the light of Lebanese law. However, the Appeals Chamber led by Judge Antonio Cassesse interpreted Lebanese law on terrorism in the light of available international consensus from case law, national legislation, treaties, and state practice, including opinio juris, on terrorism. To this end, it found that "a customary rule of international law regarding the international crime of terrorism, at least in time of peace, has indeed emerged" ${ }^{6}$ More critically, upon reviewing recent judicial decisions which considered terrorism, the Appeals Chamber noted that those decisions are "predicated on the notion that there exists an international obligation to prosecute and punish terrorism as a crime based on commonly accepted legal ingredients”. ${ }^{69}$

\section{The 21st Century Terrorist: Hostis Humani Generis?}

"Surprise, provocation, and publicity are what the terrorists are after..." [21]. ${ }^{70}$ A practicable definition of terrorism must acknowledge this innate desire for publicity and the preference for socially disruptive aggression as a means of arousing this publicity [22]. ${ }^{71}$ The terrorist is not merely an ideological criminal or even, a pathological killer content with the satisfaction of committing a crime without being caught. Although some in a group may evince these characteristics, the terrorist is much more than this. A terrorist considers that only sustained violence towards others and the wreaking of havoc in the community, can obtain the recognition of whatever it is he or she desires [23]. ${ }^{72}$ That recognition requires a pu-

\footnotetext{
${ }^{67}$ See M. Halberstam, op cit, at 573.

${ }^{68}$ STL Appeals Chamber, op cit, para 85. (Italics in original).

${ }^{69}$ Ibid, para 100

${ }^{70}$ I. Duyvesteyn, "How New is the New Terrorism” Studies in Conflict and Terrorism, Vol. 27, No. 5, 2004, pp. 439-454, at 450.

${ }^{71}$ F.J. Hacker, cited in C. H. Simmons and J. R. Mitch, "Labelling Public Aggression: When is it Terrorism," The Journal of Social Psychology Vol. 125, No. 2, 1985, pp. 245-251, at 245, noted that terrorist acts are "triadic"; dramatic events meant to involve observers and the mass media as well.

${ }^{72}$ See further, T. DeAngelis, "Understanding Terrorism” American Psychological Association, 40 (2009) available online: http://www.apa. org/monitor/2009/11/terrorism.aspx; accessed June 182012.
}

blic stage; it is not that terrorists are insensitive or unaware of the harm and pain inflicted on the many innocent victims of their activities; they see their victims as expendable publicity tools. Aware that no State and the international community will remain unmoved by the death of innocent men, women and children, they are prepared to exploit fear and human empathy in furtherance of their reign of terror. The attitude of the perpetrator even more than the ideology matters-it is this attitude that to a large extent determines the scale of the violence employed in terrorist attacks. The fact is that what we now call "terrorism" is not terrorism in the way we have always known it to be; compared with terrorism in the past there are "important differences". ${ }^{73}$

\subsection{The 21st Century Terrorist}

The perpetrators of modern terrorist attacks are not necessarily sponsored by states or political groups; they quickly form subgroups across national boundaries; they are fostered in communities often feeling the effects of war, famine, or social dislocation. Their attacks are not limited to their national or immediate territories; the ideology is as varied as their social, religious, economic or political beliefs. They do not have any agenda for disengagement or any limits to their operations which makes it difficult strategically to counter their activities. They court rather than avoid publicity, and exploit available new technologies in communication and the social media. Most importantly, they are not under any illusions that they are bound by any law, domestic or international. ${ }^{74}$ Yet, they are organised, with hierarchical leadership structures, financed, and led, just like mini-states. They assert that they are engaged in warfare with their targets but do not act as if they are bound by the rules on armed conflict. They are increasingly better co-ordinated and well trained in high technologies, espionage, money laundering, and appear to have an uncanny ability to recruit young, idealistic, intelligent and upwardly mobile men and women along with the poor and disenfranchised. Unprepared to lay down arms and without a care for collateral damage, they strike where and whenever they can-their targets are not always their victims.

Is the modern terrorist an enemy of mankind? Yes, because he operates according to his preferred rules and not within the ambit of domestic law, and as with other transnational crime, operates across borders. Whether by the use of social media or support by affiliate groups, or in pursuit of targets, by this global presence, the terrorist places himself at the mercy of any State; his decision to operate "globally" raises threats to the international com-

\footnotetext{
${ }^{73}$ J. Cilliers, op cit, 93. Duyvesteyn however questions whether there is anything fundamentally new in modern terrorism. See generally, Duyvesteyn op cit.

${ }^{74} \mathrm{Al}$-Qaeda insists it is subject only to the law of Allah.
} 
munity. The indiscriminate violence unleashed by modern terrorist activity clearly places the terrorist as an enemy of all human society. With this threat to international peace and security, criminal responsibility therefore arises: "crimes against international law are committed by men, not by abstract entities, and only by punishing individuals who commit such crimes can the provision of international law be enforced" ${ }^{75}$ The problem admittedly is with a State's willingness to exercise jurisdiction over what is considered an "international crime" although its impact is largely felt within the domestic environment. Cilliers notes that as a means of avoiding the complexities of "sub-state terrorism" and of different national systems, national legislation following UN Security Council Resolution 1373 (2001) restrict the description of terrorist acts to international acts". ${ }^{76}$ The fact that there is then no universal jurisdiction over the crime obviously limits the ability of States to pursue punishment.

Categorising terrorists as common enemies of mankind demands that all states have an obligation to apprehend terrorists, to try them or to hand them over to another country that can, to try them. Some states will not be eager to give up their nationals or those whose activities suit their own interests in global politics. But if we acknowledge that terrorism is "an act which the international community recognise as not only a violation of ordinary State criminal law but one which is so serious that it must be regarded as a matter for international concern" it therefore "cannot be left to the State which would normally have jurisdiction over it [24]". ${ }^{77}$

Today, terrorism is not only the tool of Al-Qaeda regardless of the various attempts to attach the Al-Qaeda tag to any radical extremist behaviour. Other groups hinging their actions on one platform of rights or another in previously "non-terrorist" locations are also on the rise. For instance Nigeria's southern Niger Delta militants who condemn the exploitation and environmental pollution of the region by oil companies ${ }^{78}$ and in the northern part of the country, the group Boko Haram (who want the

\footnotetext{
${ }^{75}$ Formulation of the Nuremberg Principles, ILC Year Book 1950, Commentary, at 374

${ }^{76}$ J. Cilliers, op cit, 92.

${ }^{77}$ C. de Than and E. Shorts, International Criminal Law and Human Rights (London: Sweet \& Maxwell 2003), 13.

${ }^{78}$ This group claimed responsibility for the explosions in the Federal Capital Abuja on 1 October 2010 which killed at least eight people. See J. Percival (and other agencies) "Nigeria capital rocked by bombs on $50^{\text {th }}$ independence anniversary". Online at http://www.guardian. co. uk/ world/2010/oct/01/nigeria-independence-bombs accessed August 10 2011.

${ }^{79}$ Boko Haram condemns what it refers to as the sinful Western way of life in Nigeria. A bomb attack by the group on 12 July 2011 killed at least fifty people in Maiduguri, Borno State. See E. Ibemere et al., "Nigeria: Boko Haram strikes again, kills 50 in Maiduguri." Online at: http://allafrica.com/stories/201107-131316.html accessed 29 June 2012. They are also suspected of association with a bomb attack on the UN building in Abuja on 26 August 2011.
}

country governed according to Islamic law). ${ }^{79}$ Individual imitators of the violence of terrorism are also real threats: Andres Behring Breivik massacred over 70 innocent persons in coordinated attacks (detonated car bomb explosion in Oslo, and his targeted murder of youths in a youth camp at Utoeya, on 22 July 2011 in his home country, Norway) as a means of averting attention to what he called the "islamisation of Europe". 80

Individual cases as in Breivik's above may, given their isolated circumstances, be regarded as a domestic crime; murder on a large scale. But insurgencies such as Boko haram even though it operates in Nigeria, have an international impact and must be distinguished from pure domestic criminal activity. The distinction may be a difficult one to make but it is crucial. The author of Imperial Hubris attempts such a distinction saying, "terrorists alone cannot threaten national security; terrorists who are a complimentary subset of a larger internatio na 1 ... insurgency surely can" [25]. ${ }^{81}$ Anything that destabilises and harms lives and property is a threat to national security and given its transnational impact-the killing of foreigners, destruction of foreign assets, displacement of citizens, etc., is a threat to the international community. What is vital is an acute understanding of the scale and scope of each particular threat. Such an understanding facilitates an appropriate response in countering that threat, doing so within justifiable limits, and clamping down on a "globalisation" trend in terrorism. We consider that an appropriate response is that we recognise the terrorist as hostis humanis generis - a common enemy of mankind.

\subsection{A Regime for Punishment}

A potential risk to the international community triggers what the International Court of Justice in the Barcelona Traction case, ${ }^{82}$ referred to as erga omnes obligations which States owe to the international community as a whole. ${ }^{83}$ One such obligation has been to apprehend and punish pirates. In Re Piracy Jure Gentium, the UK Privy Council noted that a pirate "is no longer a national, but "hostis humani generic" and as such he is justiciable by any State anywhere" ${ }^{84}$ By the peculiar circumstance of the crime, the pirate had placed himself beyond the protection or reaches of any state. The dissenting opinion of Justice Moore in the earlier case of the SS Lotus ${ }^{85}$ (which however arose on different grounds) elaborates on the peculiar nature of pirates as enemies of mankind:

\footnotetext{
${ }^{80}$ Breivik's 1500 page online manifesto, "2083: A European Declaration of Independence" has been described as "a chilling attack manifesto". See BBC News Europe: Online at: http:// www.bbc.co.uk/ news/ worldeurope-14267007 accessed 29 June 2012.

${ }^{81} \mathrm{M}$. Scheuer, Imperial Hubris: Why the West is Losing the War on Terror (Washington: Brassey’s Inc 2004) 220.

${ }^{82}$ Barcelona Traction, Light and Power Company (Second Phase) I. C. J. 1970.

${ }^{83}$ Ibid, paras. 33-34.

${ }^{84}(1934)$ AC 586, at 589.

${ }^{85} 1927,2$ WCR at 20.
} 
...Piracy by law of nations in its jurisdictional aspects is sui generis. Though statutes may provide for its punishment, it is an offence against the law of nations; and as the scene of the pirate's operations is the high seas, which it is not the right or duty of any nation to police, he is denied the protection of the flag which he may carry, and is treated as an outlaw, as the enemy of all mankind-hostis humani generis - whom any nation may in the interest of all capture and punish. ${ }^{86}$

The same view could be extended to the modern terrorist who bolstered by modern technology, ease of travel, and communication (on the intangible location of the internet and via the unpoliced network of social media), can direct, facilitate or carry out attacks even without being physically present. It is also instructive that many such terrorists do not consider themselves subject to any legal regime, domestic or international.

The characterisation "enemy of all mankind," when applied to terrorists, also reflects the scale and gravity of the crime. The Charter of the Nuremberg Tribunal ${ }^{87}$ setting out "crimes against humanity" relevant in time of war or peace, included:

Murder, extermination, enslavement, deportation and other inhuman acts against any civilian population, or persecutions on political, racial or religious grounds, when such acts are done or such persecutions are carried on in execution of or in connection with any crime against peace or any war crime. ${ }^{88}$

Modern terrorism certainly bears the marks of "inhuman acts against ...civilian population". ${ }^{89}$ In the light of the above, there is or at least there ought to be, a universal duty to on all states in the international community to apprehend and prosecute, or to extradite terror suspects. In a globalised world, domestic threats of terrorism ought to be a fact for universal concern when the activities of terror groups are supported or aided financially, technically, or morally, by external parties. Three leaders associated with Boko Haram, the Nigerian terror group have been officially declared as terrorists by the US government meaning any assets associated with them in the USA would be frozen [26]. ${ }^{90}$ This action is a step towards tackling the weapon of terror but more needs to be done. Having placed themselves beyond the protection of any state not only by the geographical reaches of their activity and their disavowal of their State's jurisdiction over their activities, but also by their disregard and wan- ton violation of peoples' right to life, to peaceful existence and to enjoyment of property, terrorists are certainly enemies of all mankind and should be subject to universal jurisdiction.

\subsection{Tackling Terror}

Beyond establishing a universal regime of punishment, those factors that stoke an increase in terrorism must not be ignored: oppressive regimes, unwarranted political intervention in the domestic affairs of weaker states; a general rise in social violence, unemployment, poverty, wars and internal displacement, poor education, poor social welfare, and indeed a rising disillusioned young population. Improved technologies including in financial transactions, [27] ${ }^{91}$ and a more efficient global communication network, with widespread use of social media-also facilitate terrorism [28]. ${ }^{92}$

There are other issues still: Terrorism courts publicity, at least modern "terrorists" do so. Indeed this is a defining feature of the $21^{\text {st }}$ century terrorist [29]. ${ }^{93}$ The enduring impact of the violence displayed at $9 / 11$ is that it has brought the indiscriminate violence of terrorism into the very centre of lives. It has also created mimics of this aggressive behaviour; bombs and suicide bombing previously known only to the most volatile conflict zones around the world as a deliberate terrorist strategy, [30] $]^{94}$ are now more commonly employed even in purely domestic crime. The human body has become a significant weapon of terror even as it remains terrorists' primary targets. ${ }^{95}$ Suicide bombing is appealing to terrorists for a number of reasons: a suicide bomber cannot be apprehended and cannot assist in investigations; the loyalty to their ideology is enforced by this willingness to die for their cause; their self-immolation lends to their mystery attracting future young and ideologically vulnerable recruits, and the deaths emphasizes their determination to succeed in their mission. As a weapon of terror, it also creates fear in the public, retains political attention, and

\footnotetext{
${ }^{91}$ The UN International Convention for the Suppression of the Financing of Terrorism (1999) is supposed to tackle global funding for terrorist activities by these means.

${ }^{92}$ See generally, S. A. Baker, Skating on Stilts: Why we aren't stopping tomorrow's terrorism (California: Hoover Inst Press 2010).

${ }^{93}$ See generally, European Commission Sixth Work Programme (Transnational Terrorism, Security and the Rule of Law), "Terrorism and the Media” July 232008.

${ }^{94}$ D. K. Gupta and K. Mundra, "Suicide Bombing as a Strategic Weapon: An Empirical Investigation of Hamas and Islamic Jihad”, Terrorism and Political Violence 17 (2005), 573-598.

${ }^{95}$ See R. J. Brym and B. Araj, “Are Suicide Bombers Suicidal?” Studies in Conflict and Terrorism, 35 (2012) 432-443; See R. A. Pape, Dying to Win: The Strategic Logic of Suicide Bombing (New York: Random House 2005). Cf F. Hoveyda (Review): "Dying to Win: The Strategic Logic of Suicide Bombing" American Foreign Policy Interests 27 (2005) 535-548; A. Moghadam, "Suicide Terrorism, Occupation, and the Globalisation of Martyrdom," Studies in Conflict and Terrorism 29 (2006), 707-729.
} 
even arouses sympathy.

The delay in properly perceiving terrorists for the common enemies they are in our globalised world, has brought huge costs: death, destruction of property, social instability, impact on transportation and tourism, environmental destruction including the continued threat of the use of WMDs, and of course, the constant fear exacerbated by national security warnings and ever-tightening border control measures, costs of military, legal, and political efforts in counter-terrorism. Military power may delay further terrorist activity on the scale of 9/11 but if the "common enemy" is not willing to end violent attacks, and indeed continues to inspire new armies-who employ means of large-scale social destruction even with differing ideologies - the terror will not end. In addition to the search for a legal regime, we must acknowledge the need for alternative social responses to military counter-terrorism, and respond to the background issues that facilitate the emergence of new terrorist units.

\section{Alternative Social Responses}

Post 9/11, the war on terror has spawned other wars: Iraq; Afghanistan, and the huge costs of continued military action around the world [31]. ${ }^{96}$ It has exacerbated tensions between Muslims and adherents of other religions. It has garnered increased international criticism for unilateral action with civilian casualties, in particular drone strikes by the US in Pakistan. As the threats spread farther a field, there is a possibility of society slowly developing a shock-immunity syndrome to threats of terrorism-a perception of acts of terrorism as terrible but just another common-place event in society; indeed this is a fact of life in a number of places now including in Northern Nigeria. While the Boko Haram threat is spiralling out of control, there is no legislation that provides for their apprehendsion or punishment. The current "law enforcement" approach is for security forces to shoot to kill any person they decide is a member of the group [32]. ${ }^{97}$ The inevitable execution of innocent civilians cannot be discounted and indeed this was the case in the first publicised security response to the Boko Haram threat. ${ }^{98}$ Action such as this by the Nigerian security forces is a typical response- the belief that fire power will quench dissidents. It has so far proved unsuccessful and the threat of Boko Haram continues unabated.

\footnotetext{
${ }^{96}$ See the various reports by the Bureau of Investigative Journalism: "Covert War on Terror", online at: http://www.thebureauinvestigates. com/category/projects/drones, accessed 29 June 2012.

${ }^{97}$ See Al-Jazeera, "Video shows Nigeria Executions", online at: http://www.aljazeera.com/news/africa/2010/02/2010298114949112.htm l accessed June 28 2012. The video on this web site taken in February 2012 in the aftermath of attacks claimed by the group is horrific. Security forces drag out and shoot civilians at point blank rage without any pretence at trial.

${ }^{98}$ Ibid.
}

Our general revulsion against terrorists' acts must not be eroded by slow political action at both the domestic and international level or by an insistence on what is clearly a futile effort-attempting to define ideologies and motives while ignoring the dangers and disasters caused by wilful acts of violence in the social sphere. The inevitable shift in political interests in the 21st century requires a tactical approach to inclusive dialogue which identifies, respects, and addresses the views of changing global political alliances and divergent social, economic and political understandings. Fostering an awareness of emerging views and perspectives on global rights' issues is also crucial: civil liberties, poor social welfare, political disenfranchisement, religious propaganda, unequal social systems, corrupt governments weak institutions, unwarranted and sustained intervention into the politics of dependent countries, easy availability of arms and ammunition, global access to new technologies-are only some of the issues which form the basis of a number of terrorist attacks today-avoiding a debate on these admittedly sensitive issues merely disregards addressing differences and areas of potential conflict.

Military intervention is not the best means of addressing the root causes of terrorism. It may be a long process, but effecting change from within societies and with their involvement, may be a more lasting solution than external military intervention often viewed as an imposition of alien ideologies for the benefit of foreign interests. Nevertheless, law, politics, and international relations need to come to grips with modern realities - the issues that plagued the human society in the last century have given way to new ones. New responses must be found to this new century's issues, a significant one of which is the emergence of a new common enemy with equal access to new technologies [33] ${ }^{99}$ and whose channel of communicating its ideas is a unique brand of public large-scale social violence.

\section{Conclusions}

Psychologists have described terrorism as being distinguishable from other aggression "by the motivation of the terrorist to gain publicity from his or her actions". 100 Aggression is however a concept peculiarly defined in international law to cover acts carried out by state entities against another state. Terrorist activity including action across borders is therefore out with the scope of aggression. This paper has argued for a better appreciation of modern terrorist activities and for a perception that ac-

\footnotetext{
${ }^{99}$ While it may not directly and visibly result in human deaths, the threat of cyber crime and the huge financial and economic losses this can bring to businesses, companies, industries, organisations, and governments cannot be ignored. See BBC News "MI5 Boss Jonathan Evans Warns over Cyber Threat,” 26 June 2012, http://www.bbc.co.uk/news/uk-18590209, accessed June 282012.

${ }^{100}$ C. H. Simmons and J. R. Mitch, op cit, 245.
} 
knowledges the modern terrorist's determination to deliberately, aggressively, publicly, and violently disrupt the social space for the sake of creating terror.

The successes of domestic and bilateral action are limited to the countries who can afford to undertake these paths to combating terrorism. For the international community, the perception of the terrorist regardless of his modus operandi, as an enemy of mankind, is vital to any international effort at punishing and deterring the violence of terrorism. This is not to deny that there are outstanding issues. There is the fact of state terrorism and state-sponsored terrorism and the political willingness (and capacity) of the international community to address these issues. There is also the issue of tyrannical and oppressive regimes, to which victims over time have responded to with violence. The 2011 Appeal Chamber of the Special Tribunal for Lebanon's ruling is a step forward in placing terrorism in its proper context-a grave international crime. Still, the violence of terror magnified by its increasing sophistication and the indiscriminate killing of people as a means to satisfying some questionable motives requires a more determined response to what is progressively becoming a disregard for, and a violation of, our shared humanity. International law must respond to those who do not consider that safeguarding our common peace and security is an obligation to be respected. Whatever ideology, motive or purpose that drives modern terrorist activity, their unbridled violence and threat to human peace and security in the $21^{\text {st }}$ century, makes the terrorist a common enemy of mankind.

\section{Acknowledgements}

The author is indebted to the anonymous reviewers for their invaluable comments and suggestions.

\section{REFERENCES}

[1] B. Saul, “Attempts to Define 'Terrorism' in International Law,” Netherlands International Law Report, Vol. 52, No. 1, 2005, pp. 57-83.

[2] A. Cassesse, "The Multifaceted Criminal Notion of Terrorism in International Law," Journal of International Criminal Justice, 2006, pp. 1-26. doi:10.1093/jicj/mq1074

[3] B. Saul, "Definition of 'Terrorism' in the UN Security Council: 1985-2004," Chinese Journal of International Law, Vol. 4, No. 1, 2012, pp. 141-166. doi:10.1093/chinesejil/jmi005

[4] A. van Engeland and R. M. Rudolph, "From Terrorism to Politics,” Ashgate, Hampshire, 2008.

[5] C. J. Tams, "The Use of Force against Terrorists," European Journal of International Law, Vol. 20, No. 2, 2009, pp. 359-397. doi:10.1093/ejil/chp031

[6] N. Rostow, "Before and after: The Changed UN Response to Terrorism Since Sept. 11,” Cornell International
Law Journal, Vol. 35 No. 35, 2001, pp. 475-481.

[7] T. Wright, "Pakistan Criticises US Raid on Bin Laden," 2011.

http://online.wsj.com/article/SB100014240527487039228 04576301124180651068.html

[8] B. Hoffman, "Inside Terrorism,” Columbia University Press, New York, 1998.

[9] A. Cassesse, "International Law," 2nd Edition, Oxford University Press, New York, 2005.

[10] M. Hmoud, "Negotiating the Draft Comprehensive Convention on International Terrorism-Major Bones of Contention,” Journal of International Criminal Justice, Vol. 4, No. 5, 2006, pp. 1031-1043. doi:10.1093/jicj/mql081

[11] J. Rehman, “International Human Rights Law,” 2nd Edition, Pearson Education Ltd., England, 2010.

[12] STL Appeals Chamber: "Interlocutory Decision on the Applicable Law: Terrorism, Conspiracy, Homicide, Perpetration, Cumulative Charging," 2011.

[13] J. K. Young and M. G. Findley, "Promise and Pitfalls of Terrorism Research,” International Studies Review, Vol. 13, No. 3, 2011, pp. 411-439. doi:10.1111/j.1468-2486.2011.01015.x

[14] J. Dugard and C. van den Wyngaert, "Reconciling Extradition with Human Rights,” American Journal of International Law, Vol. 92, No. 187, 1998, pp. 187-212.

[15] C. van den Wyngaert, "Applying the European Convention on Human Rights to Extradition: Opening Pandora’s Box?” International Comparative Law Quarterly, Vol. 39, No. 4, 1990, pp. 757-779.

[16] M. Cherif-Bassiouni, “International Extradition,” United States Law and Practice, 1983.

[17] D. S. Kris, "Law Enforcement as a Counterterrorism Tool," Journal of National Security Law and Policy, Vol. 5, No. 1, 2011, pp. 1-95.

[18] J. Cilliers, “Terrorism and Africa,” African Security Review, Vol. 12, No. 4, 2003, pp. 91-103. doi:10.1080/10246029.2003.9627255

[19] B. Vaughan, et al., “Terrorism in South East Asia,” In: P. Chalk, et al., Eds., The Evolving Terrorist Threat to South East Asia: A Net Assessment CSR Report for (US) Congress, Virginia, 2009.

[20] M. Shaw, "International Law," 6th Edition, Cambridge University Press, Cambridge, 2008. doi:10.1017/CBO9780511841637

[21] I. Duyvesteyn, “How New Is the New Terrorism,” Studies in Conflict and Terrorism, Vol. 27, No. 5, 2004, pp. 439454.

[22] F. J. Hacker, C. H. Simmons and J. R. Mitch, "Labelling Public Aggression: When Is It Terrorism," The Journal of Social Psychology, Vol. 125, No. 2, 1985, pp. 245-251.

[23] T. De Angelis, "Understanding Terrorism,” American Psychological Association, 2009.

http://www.apa.org/monitor/2009/11/terrorism.aspx

[24] C. de Than and E. Shorts, "International Criminal Law and Human Rights,” Sweet \& Maxwell, London, 2003. 
[25] M. Scheuer, "Imperial Hubris: Why the West Is Losing the War on Terror,” Brassey’s Inc., Washington, 2004.

[26] BBC News, "Boko Haram Leaders are Designated as Terrorists by US,” 2012.

http://www.bbc.co.uk/news/world-africa-18542030

[27] The UN International Convention for the Suppression of the Financing of Terrorism, 1999.

[28] S. A. Baker, "Skating on Stilts: Why We Aren't Stopping Tomorrow's Terrorism,” Hoover Inst Press, California, 2010.

[29] European Commission Sixth Work Programme (Transnational Terrorism, Security and the Rule of Law), "Terrorism and the Media,” 2008.

[30] D. K. Gupta and K. Mundra, "Suicide Bombing as a Stra- tegic Weapon: An Empirical Investigation of Hamas and Islamic Jihad,” Terrorism and Political Violence, Vol. 17, No. 4, 2005, pp. 573-598. doi:10.1080/09546550500189895

[31] Bureau of Investigative Journalism, "Covert War on Terror,” 2012.

http://www.thebureauinvestigates.com/category/projects/ drones/

[32] Al-Jazeera, “Video shows Nigeria 'Executions',” 2012. http://www.aljazeera.com/news/africa/2010/02/20102981 14949112.html

[33] BBC News, "MI5 Boss Jonathan Evans Warns over Cyber Threat,” 2012.

http://www.bbc.co.uk/news/uk-18590209 